\title{
Seventeenth-Century Fiction in the Making
}

\section{Isabelle Moreau}

Innovation in prose fiction took Europe by storm during the seventeenth century. New-style romances, novels reinvented from older forms and sources, histoires effectively mixing history with romance tropes: no single umbrella term can capture the astonishing variety of fictional experiments witnessed at the time. Challenging standard scholarly narratives about the rise of the novel, Seventeenth-Century Fiction: Text and Transmission comes to grips with the instabilities of prose fiction during the seventeenth century. It emphasizes the interchange between classical and vernacular languages, popular and elite cultures, stage and page. By doing so, it aims to uncover the variety of old and new forms that readers craved, and that could not be subsumed within a limited definition of the novel.

This book examines the diverse trends of fictional prose forms at a critical moment in the history of modern fiction. It situates seventeenth-century prose fiction within a variety of discursive, generic, material, and linguistic traditions. It thus pays particular attention to the physical media through which prose fiction was transmitted across national and linguistic frontiers. It is our contention that prose fiction is better understood when considered as a trans-European phenomenon. Rather than attempting to construct a grand narrative, ${ }^{1}$ we have

\footnotetext{
${ }^{1}$ We fully acknowledge the importance of existing historical theories. Since the pioneering investigation of Ian Watt in The Rise of the Novel: Studies in Defoe, Richardson and Fielding (London: Chatto \& Windus, 1957), important debates have been conducted on the construction of prose fiction as a category, which opened the English tradition to continental influences and emphasized the role played therein by women's writing. The following list is not meant to be
} 
opted for a series of case studies set against the backdrop of the provisional map of the field that this introduction provides. We hope to give here through specific examples an impetus towards a better understanding of the range of material to which early modern readers had

exhaustive but should give a sense of research in the field: Philip Stewart, Imitation and Illusion in the French Memoir-Novel, 1700-1750: The Art of Make-Believe (New Haven, CT: Yale University Press, 1969); Ioan Williams, The Idea of the Novel in Europe, 1600-1800 (London: Macmillan, 1978); Lennard J. Davis, Factual Fictions: The Origins of the English Novel (New York: Columbia University Press, 1983); Paul Salzman, English Prose Fiction 1558-1700: A Critical History (Oxford: Clarendon Press, 1985-6); Barbara Foley, Telling the Truth: The Theory and Practice of Documentary Fiction (Ithaca, NY: Cornell University Press, 1986); Michael McKeon, The Origins of the English Novel, 1600-1740 (Baltimore, MD: Johns Hopkins University Press, 1987) as well as 'Review: The Origins of the English Novel', Modern Philology 82, no. 1 (August 1984): pp. 7686, <http://www.jstor.org/stable/437677>, and Theory of the Novel: A Historical Approach, edited by Michael McKeon (Baltimore, MD: Johns Hopkins University Press, 2000); Paul J. Hunter, Before Novels: The Cultural Contexts of Eighteenth-Century English Fiction (New York: Norton, 1990); Catherine Gallagher, Nobody's Story: The Vanishing Acts of Women Writers in the Marketplace, 1670-1820 (Oxford: Clarendon Press, 1994), and 'The Rise of Fictionality', in The Novel, vol. 1: , edited by Franco Moretti (Princeton, NJ: Princeton University Press, 2006), pp. 336-63; Robert Mayer, History and the Early English Novel: Matters of Fact from Bacon to Defoe (Cambridge: Cambridge University Press, 1997); Margaret Anne Doody, The True Story of the Novel (New Brunswick, NJ: Rutgers University Press, 1996); Dorrit Cohn, The Distinction of Fiction (Baltimore, MD: Johns Hopkins University Press, 1999); Nicholas D. Paige, Before Fiction: The Ancien Régime of the Novel (Philadelphia: University of Pennsylvania Press, 2011). The collective volume edited by Jenny Mander, Remapping the Rise of the European Novel (Oxford: Voltaire Foundation, 2007), presents a renewed, comprehensive view of (mostly) eighteenth-century fiction within a comparative framework that traces continuities in novelistic production across time and national boundaries. 
access, as well as a sense of how diverse were the reception and perception of prose fiction at the time.

This book uses the term 'prose fiction' to encompass early modern fictional texts in prose, while remaining fully aware that fiction in this period, although 'fundamental to the making of literary texts' ${ }^{2}$ is not restricted to them or indeed 'coterminous with literature'. 3 Conversely, fiction does not equate with 'fictionality', if by this we mean 'the peculiar yet for us intuitive way that [contemporary] novels refer to the world' ${ }^{4}$ Prose fiction here rather gestures towards a body of narrative texts that, while constantly playing on the outskirts of history as a genre, are not seen as works of history as such - no more, in fact, than they are read as 'fact dressed up as fiction'. ${ }^{5}$ Prose fiction is also understood as a substitute term for a series of categories such as 'romance', 'novella' and 'novel', 'romanza', 'roman' and 'roman héroïque', 'nouvelle historique', 'histoire', and 'histoire secrète', to name but a few. These

\footnotetext{
${ }^{2}$ Richard Scholar and Alexis Tadié, 'Introduction', in Fiction and the Frontiers of Knowledge in
} Europe, 1500-1800, edited by Richard Scholar and Alexis Tadié (Farnham: Ashgate, 2010), pp. 115 (p. 1).

${ }^{3}$ Paige, Before Fiction, 'Introduction', p. ix.

${ }^{4}$ Paige, Before Fiction, 'Introduction', p. ix.

${ }^{5}$ Jennifer Lee Carrell, 'A Pack of Lies in a Looking Glass: Lady Mary Wroth's Urania and the Magic Mirror of Romance', Studies in English Literature, 1500-1900 34, no. 1, The English Renaissance (Winter 1994): pp. 79-107 (pp. 80, 87), <http://www.jstor.org/stable/450787>. As such we hope to avoid using 'fiction' as a catch-all term, one that is 'used when generic objections are feared or when genre is uncertain' (Paige, Before Fiction, p. 3). On the relationship between fiction and history, see Allison Kavey, ed., Fictional Histories/Historical Fictions: Reconceptualizing History in Early Modern Literature (Farnham: Ashgate, forthcoming 2016). I am grateful to Alex Davis for making available to me his forthcoming chapter, provisionally entitled: “"A Fable Like a Historie”: Lady Mary Wroth's "Heathen Fiction”. 
terms, although in use at the time, are problematic, especially when considered across national and linguistic frontiers. In English, the very definition of romance is far from stable throughout the period, ${ }^{6}$ and this instability greatly undermines the romance-novel opposition; while in French, we get the impression that 'French culture produces a Nouveau Roman every few generations', ${ }^{7}$ each subgenre defining itself against its supposedly superseded predecessor. In other words, the claim of novelty, which often triggers the urge of renaming, should be taken for what it is: a claim directed polemically at former subgenres or literary forms as a means of asserting one's own legitimacy ${ }^{8}$ and a claim which is also a commercial strategy. When the publisher Anne Moseley advertises some twenty-one 'Other Excellent Romances' at the end of Cassandra in 1667, she clearly exploits 'this desire for freshness and newness' in the crafting of the titles. ${ }^{9}$ We are not implying here that claims of innovation were empty words, or that they could not stimulate any change; rather that our own preconceptions about the novelistic form need to be put to the test and confronted with what

\footnotetext{
${ }^{6}$ English prose fiction in the Renaissance often defies all generic boundaries: see Nandini Das, Renaissance Romance: The Transformation of English Prose Fiction, 1570-1620 (Farnham:
} Ashgate, 2011).

${ }^{7}$ James Grantham Turner, “"Romance” and the Novel in Restoration England', Review of English Studies 63 (2012): pp. 58-85 (p. 68), doi:10.1093/res/hgr041.

${ }^{8}$ Laurence Plazenet, 'Romanesque et roman baroque', in Le Romanesque, edited by Gilles Declercq and Michel Murat (Paris: Presses Sorbonne Nouvelle, 2004), pp. 63-84. See also Turner, "'Romance" and the Novel', p. 69, on innovation and novelty; and Das, Renaissance Romance, on the 'temporal and generational consciousness integral to romance' that came to be coded into romance by means of 'tropes of generational negotiation' ('Introduction', p. 3).

${ }^{9}$ Turner, “"Romance” and the Novel', pp. 69-70; and [Gautier de Costes de La Calprenède], Cassandra, the Fam'd Romance, trans. Charles Cotterell (London: Printed for A. Moseley, 1667), p. 858 . 
was not only written and read at the time, but also commented on and written about. To chart seventeenth-century prose fiction, one has to look at prefaces and translators' notes, Bibliothèques and other compendia of titles and authors, as well as at the texts themselves and, within them, at scenes and discussions that reflect upon the composition, production, translation, and reception of fictional texts.

If the literary production of the time lacks 'an established generic name', ${ }^{10}$ the problem is not just that of terminology. The evolution of forms reveals continuities as well as discontinuities that may lead to interpretations which rely on conflicting epistemological frameworks. The succession of subgenres may be taken as supporting evidence for an evolutionary model, positing a development from improbable, far-fetched romances to the historical novella, or nouvelle historique. Or it may cast doubts on the relevance of such an evolution, whether it is understood as a slow rise or as a series of epistemological or more practical ruptures. ${ }^{11}$ Let us consider, for instance, the 1667 edition of Charles Sorel's Bibliothèque françoise. ${ }^{12}$ Sorel's chapter on fictional narratives, which provides a survey of the French book market up to the 1660s, shows that, in seventeenth-century France, readers and practitioners alike did not adhere to a limited definition of the novelistic form. By the same token, it gives a sense of how the term 'Roman', which by common usage came to be applied to all kind of 'Livres de fiction' (says Sorel), ${ }^{13}$ was indeed understood as an

\footnotetext{
${ }^{10}$ Turner, "'Romance" and the Novel', p. 59.

${ }^{11}$ See Paige, Before Fiction, p. 24.

${ }^{12}$ Charles Sorel, La Bibliothèque françoise [2nd edn., 1667] (Geneva: Slatkine Reprints, 1970). All references are to this edition.

${ }^{13}$ Sorel, La Bibliothèque françoise, chapter 9, pp. 51-60 [1667 edn.: 166-200]: 'Des fables et des allegories, des romans de chevalerie et de bergerie; des romans vray-semblables et des nouvelles; des romans heroïques et des comiques': p. 55 [181]. Sorel notes that even if the term 'roman' was
} 
encompassing category able to subsume a series of fictional experiments with their dominant themes and formal characteristics. Sorel opens his chapter with allegory, from translations of classics such as Ovid's Metamorphoses to more recent allegorical maps, then moves on to the chivalric romance, thereafter explaining the rising importance of the pastoral romance by readers' weariness of knightly deeds. ${ }^{14}$ He then defines with some difficulty the section on short stories and romans of a plausible nature ('Des romans vray-semblables et des nouvelles'), presents the heroic romance as a French success, despite its mythical Greek origins, and ends his survey with the comic novel. In a context of increasing distrust towards fiction and theatre in France, it is worth noting that Sorel does not feel the need for an apology. His criteria are aesthetic rather than moral. While naming the books worth reading, Sorel appraises them according to two sets of criteria: the politeness of the style and the verisimilitude (or 'vraisemblance') of the story. Although he does not organize the various subgenres of narrative prose fiction hierarchically, his comments about stylistic progress and change of taste create, in effect, a teleological narrative. Sections and subsections are included in a historical survey ('Nous suivrons icy l'ordre des Temps' ${ }^{15}$ ), which is also tacitly an evolutionary one. We are left with a representation of the history of fiction that has come to look quite familiar to us precisely because of the efforts of Sorel and others to construct it.

first coined to describe chivalric romances, it is now used as an umbrella term. See also Camille Esmein-Sarrazin, L'Essor du roman. Discours thèorique et constitution d'un genre littéraire au XVII siècle (Paris: Honoré Champion, 2008), pp. 36-43. Conversely, Christine S. Lee notes, 'What is startling about "romance" in the Renaissance is how much the term excludes' (Christine S. Lee, 'The Meanings of Romance: Rethinking Early Modern Fiction', Modern Philology 112, no. 2 (November 2014): pp. 287-311, doi: 10.1086/678255).

${ }^{14}$ Sorel, La Bibliothèque françoise, p. 53 [175].

${ }^{15}$ Sorel, La Bibliothèque françoise, p. 55 [180]. 
In many ways, Sorel's chapter on fictional narratives falls conveniently into a pattern, that of a series of mutually exclusive literary forms. It is worth noting, however, what disrupts such an evolutionary model. If we move on easily from allegories to chivalric and pastoral romances, to heroic romances, ${ }^{16}$ with each subgenre being presented as an attempt to achieve a more plausible narrative, the section on 'Des romans vray-semblables et des nouvelles' should have been the culmination of an aesthetic shift from far-fetched stories to plausible novellas as exemplified by La Princesse de Montpensier which, says Sorel, had quite a success in polite society because of its style 'tout à fait de l'air du beau Monde'. ${ }^{17}$ Sorel, however, still presents the heroic romance as a literary achievement. Even if the novella has become the dominant form, the heroic romance remains the highest aesthetic reference point. ${ }^{18}$ And while we tend to associate the novella with modernity, Sorel highlights its roots in Renaissance short narratives and story collections in prose. ${ }^{19} \mathrm{With}$ the last section, on comic novels, a whole new continent seems to emerge disrupting expected patterns even more. Cyrano's novels, Godwin's Man in the Moon, and Kepler's Somnium (in translation) figure among short pieces written in the gallant vein, and satires and portraits placed under Lucian's patronage. The Spanish tradition figures prominently, again in translation, alongside Sorel's own novels, L'Histoire comique de Francion, Polyandre, and Le Berger

\footnotetext{
${ }^{16}$ The category 'roman héroïque' was coined by Sorel, according to Camille Esmein, ed., Poétiques du roman. Scudéry, Huet, Du Plaisir et autres textes théoriques et critiques du XVII siècle sur le genre romanesque (Paris: Honoré Champion, 2004), p. 115.

${ }^{17}$ Sorel, La Bibliothèque françoise, p. 55 [180].

${ }^{18}$ See Sorel, La Bibliothèque françoise, p. 55 [181]: the 'romans héroïques' are equated to 'Romans Parfaits'.

${ }^{19}$ Sorel, La Bibliothèque françoise, p. 54 [178-9]. The subsection 'Des romans vray-semblables et des nouvelles' thus includes Italian, French, and Spanish references.
} 
extravagant - which ridicules the taste for pastoral romance in a transparent attempt to rival Don Quixote. Two overarching categories seem to emerge from this chaos, which contrasts shockingly with the previous, relatively well-defined subsections. The first category refers to texts called by Sorel 'pieces agreables', and includes short pieces of work such as games, portraits, and other collective writing exercises devoted to the pleasure and recreation of polite society. ${ }^{20}$ The second category applies to narrative fictions of some length ('grandes \& ... narratives' $)^{21}$ and covers two classic masterpieces, Lucian's stories and Apuleius's Golden Ass; sixteenth-century narrative fictions dubbed 'railleries à la vieille Gauloise' alongside Rabelais's masterpieces; translated Spanish picaresque novels and, among contemporary French works, the novels of Cyrano, Tristan l'Hermite, Sorel, Scarron (under the subcategory of 'burlesque'); and, eventually added to the second edition of the Bibliothèque françoise, Furetière.

Such a survey raises a number of questions regarding the applicability of the evolutionary model. True, readers and practitioners of prose fiction alike seemed to have had a strong sense of the passing modes, as indeed 'chaque Siecle a ses modes'. ${ }^{22}$ Dichotomies between old and new types of fictions are worth noting, especially as similar dichotomies were developed elsewhere in Europe. They do not necessarily build up into an evolutionary model. However, they give us an indication of the most appealing or dominant form of prose fiction at any given time, and they may give us some indication of the complex mechanisms of distinction and imitation that governed writing and reading practices. In seventeenthcentury England, according to Salzman, 'the major change in theories of prose fiction

\footnotetext{
${ }^{20}$ Sorel, La Bibliothèque françoise, p. 57 [191].

${ }^{21}$ Sorel, La Bibliothèque françoise, p. 57 [191].

${ }^{22}$ Sorel, La Bibliothèque françoise, p. 55 [183]; see also p. 53 [175]; p. 54 [177]; p. 56 [187].
} 
occurred through discussions of the political implications of the romance form ${ }^{23}$ and Jacqueline Glomski sees Barclay's Argenis as a milestone for the way it efficiently combined political ideas with the plot line of a love story. ${ }^{24}$ Barclay's characters conveyed his political ideas in a 'performative way' and furnished Argenis with a 'dramatic quality' that was quite unprecedented. First published in Paris in 1621, in Latin, Argenis proved extremely popular in Europe and the preface 'To the reader' accompanying Sir Percy Herbert's finally completed Princess Cloria (1661) comes as a testimony to its lasting influence in England, since it advocates the superiority of political romance over 'a bare historical relation that

${ }^{23}$ Paul Salzman, 'Theories of Prose Fiction in England: 1558-1700', in The Cambridge History of Literary Criticism, vol. 3: The Renaissance, edited by Glyn P. Norton (Cambridge: Cambridge University Press, 1999), pp. 293-304 (p. 300), <http://dx.doi.org/10.1017/CHOL9780521300087.031>. See also Annabel M. Patterson, Censorship and Interpretation: The Conditions of Writing and Reading in Early Modern England (Madison, WI: University of Wisconsin Press, 1984); Nigel Smith, Literature and Revolution in England, 1640-1660 (New Haven, CT: Yale University Press, 1994); Lois Potter, Secret Rites and Secret Writing: Royalist Literature 1641-1660 (Cambridge: Cambridge University Press, 1989); Victoria Kahn, 'Reinventing Romance, or the Surprising Effects of Sympathy', Renaissance Quarterly 55, no. 2 (Summer 2002): pp. 625-61 (pp. 626, 630), doi: 10.2307/1262320; Amelia A. Zurcher, Seventeenth-Century English Romance: Allegory, Ethics and Politics (Basingstoke: Palgrave Macmillan, 2007).

${ }^{24}$ See in the present volume Jacqueline Glomski's chapter, 'Politics and Passion: Fact and Fiction in Barclay's Argenis'. See also Mark Riley and Dorothy Pritchard Huber, introduction to John Barclay, Argenis, edited by Mark Riley and Dorothy Pritchard Huber, 2 vols. (Assen: Royal Van Gorcum, 2004), pp. 11, 14, 35; Salzman, English Prose Fiction 1558-1700, pp. 149-51. 
gives no liberty for inward disputations or supposed passions to be discovered' ${ }^{25}$ Interestingly, the same preface also distinguishes Princess Cloria from French heroic 'Romances' ${ }^{26}$ which were highly popular in England in the 1650s and early 1660s. William Congreve's preface to Incognita (1692) also contains an attack on the 'lofty language' and complex plot lines with 'miraculous contingencies' of seventeenth-century French romances, this time to promote the 'novel' in the comic vein. ${ }^{27}$ Yet, one should be wary of taking at face value comments about one's own distinctiveness, particularly when it comes to gauge the continuing currency of the 'old'. Notwithstanding the dominant narrative of newness, it is not rare to find examples of authors boasting about their rejection of the ethos of romance, while still drawing on many of its stock situations and conventions in their books. Herbert's Princess Cloria, though keen to distinguish itself from French heroic romances, reproduces the narrative strategy of its most influential and acknowledge model, that of Heliodorus's Aethiopica, which was also Barclay's primary model ${ }^{28}$ Lengthy speeches 'oftentimes continued for five or six hours together without intermission' are dismissed for being

${ }^{25}$ The Princess Cloria, 'Preface', in Paul Salzman, ed., An Anthology of Elizabethan Prose Fiction (Oxford: Oxford University Press, 1991), p. 214.

${ }^{26}$ The first and second parts of The Princess Cloria were published anonymously by Sir Percy Herbert of Powis as Cloria and Narcissus in 1653 and 1654 respectively. The 1661 complete edition was again published anonymously and accompanied by a preface, which was 'an extremely important contribution to the growing analysis, during the seventeenth century, of the relationship between fictional genres and ideological ends' (Salzman, ed., An Anthology: 'Introduction', p. xvii). See also Turner, “"Romance” and the Novel', p. 61.

${ }^{27}$ William Congreve, 'Preface', Incognita (1692), in Salzman, ed., An Anthology, p. 474.

${ }^{28}$ See Victoria Kahn, 'Reinventing Romance', p. 634. 
'ridiculous' and tiresome, ${ }^{29}$ which does not prevent Princess Cloria from running to some six hundred pages by 1661 . The preface incidentally acknowledges a 'style and manner of contrivance ... mixed between modern and antique'. ${ }^{30}$ Across the Channel in the 1670s, prefaces and critical treatises openly situate novelistic production against the heroic romance, but the new fictional form that supposedly gains precedence is far from constituting a homogeneous category. ${ }^{31}$

Authors are usually 'so fond of a preface that they will write one, through there be nothing more in it than an apology for itself' - says Congreve. ${ }^{32}$ Prescriptive discourses advocate categories of old and new, antique and modern. They justify the validity of the norm they spell out by turning some common features into prescriptive laws. By doing so, they also actively contribute to identifying invention with reformation and renewal, thus extolling the merit of a selected set of texts while dismissing the rest. As a consequence, prescriptions conveyed by prefaces, apologies, and treatises are more than often conflated with exemplary models, even if these models may not always follow these didactic rules for fiction, or indeed reflect the literary scene as a whole. In France, Pierre de Caseneuve, ${ }^{33}$ Jean Baudoin, ${ }^{34}$

${ }^{29}$ The Princess Cloria, 'Preface', in Salzman, ed., An Anthology, p. 213.

${ }^{30}$ The Princess Cloria, 'Preface', in Salzman, ed., An Anthology, p. 212.

${ }^{31}$ Esmein, ed., Poétiques du roman, pp. 539-40; Paige, Before Fiction, p. 56, emphasizes 'the profound commonality between the historical novella and the historical romance'.

${ }^{32}$ William Congreve, 'Preface', Incognita (1692), in Salzman, ed., An Anthology, p. 473.

${ }^{33}$ Pierre de Caseneuve, Caritée ou La Cyprienne amoureuse . . . (Tolose: D. et P. Bosc, 1621). See Esmein, ed., Poétiques du roman, p. 25.

${ }^{34}$ Jean Baudoin, Les Amours de Clytophon et de Leucippe. Traduction nouuelle, Tirée du Grec d'Achilles Tatius \& diuisée en huict livres (Paris: Quinet \& Fevrier, 1635). See Esmein, ed., Poétiques du roman, p. 25. Baudoin also translated Sydney's Arcadia and Tasso's Jerusalem 
George and Madeleine de Scudéry in their prefaces to Ibrahim (1641) and Artamène ou le Grand Cyrus (1649), and Pierre-Daniel Huet in all the editions of his Traité de l'origine des romans (from 1670 to 1711 ) take Heliodorus's Aethiopica as a model. ${ }^{35}$ The poetics of romance, from Chapelain and Scudéry to Du Plaisir, while referring to Heliodorus as an authority, also rely heavily on Aristotle's Poetics, or rather, on its interpretation by sixteenthcentury Italian scholars and poets such as Torquato Tasso, thus discarding the influence of the earlier romance epics of Matteo Maria Boiardo and Ariosto. ${ }^{36}$ The romances most often quoted and referred to as milestones are those of Honoré d'Urfé and Scudéry and, to a lesser extent, of Gomberville and La Calprenède. As for the novella, which was constituting itself against the epic model and the codification of its poetics, the most frequently referenced works are those of Lafayette, immediately followed by the 'nouvelles' of Mme de Villedieu

Delivered, alongside Godwin's Man in the Moon, and historians such as Cassius Dio and Suetonius. See L'Arcadie de la Comtesse de Pembrok, Mise en nostre langue, de l'Anglois de Messire Philippes Sidney (Paris: T. Du Bray, 1624-5); and Hiérusalem deslivrée, poème hérö̈que de Torquato Tasso mis en nostre langue par I. Baudoin (Paris: M. Guillemot, 1626).

${ }^{35}$ The first translation in French is that of Jacques Amyot, L'Histoire Aethiopique de Heliodorus, contenant dix livres, traitant des loyales et pudiques amours de Theagenes Thessalien, \& Chariclea Aethiopienne, nouvellement traduite de Grec en Françoys (Paris: J. Longis, 1547), and is accompanied by an important preface (the 'Proesme du Translateur'). See Laurence Plazenet, 'Révolution ou imposture? De l'imitation à l'invention du roman grec en France aux XVI et XVII siècles', in Commencements du roman, edited by Jean Bessière (Paris: Honoré Champion, 2001), pp. 23-47.

${ }^{36}$ Peter V. Marinelli, Ariosto and Boiardo: The Origins of Orlando Furioso (Columbia, MO: University of Missouri Press, 1987); Jo Ann Cavallo, The Romance Epics of Boiardo, Ariosto, and Tasso: From Public Duty to Private Pleasure (Toronto: University of Toronto Press, 2004). See also Esmein, ed., Poétiques du roman, p. 28. 
and Catherine Bernard. Compared to the overview of prose fiction offered by the Bibliothèque françoise, one cannot help but notice what we have lost. Allegories, portraits, and other short pieces in the gallant vein, which were so fashionable in the very circles that helped promote the heroic romance, are nowhere to be seen; but one could argue that they are indirectly represented within the romances and novellas themselves, given the propensity of books of the period to incorporate such materials in order to satisfy the audience's taste. ${ }^{37}$ Comic novels, however, are conspicuously absent from the official literary scene. Yet they demonstrate through both formal and moral experiments the extraordinary vitality of novelistic production of the time. From the Berger extravagant-Sorel's famous 'AntiRoman'38 - to the Roman bourgeois, the requirement of verisimilitude as a formal convention in the making of prose fiction serves in comic novels to promote ironic distance rather than involvement and identification. Reflexivity is another defining feature inasmuch as comic novels presuppose a readership aware of the literary conventions that are mimicked or parodied. Such subversions that extend well beyond romance tropes to better thwart the reader's thirst for irrational stories are analysed by Nicolas Correard in his chapter on picaresque novels and histoires comiques: ${ }^{39}$ there, the 'novelization' of demonological stories and their full demystification go together, thus turning the narrative make-believe into an art of doubting. In other words, comic novels played their part prominently, contributing much to what Nandini Das calls 'the self-conscious use of the implausible and the improbable' in romance. When prose fiction experiments with its form by playing with what it is not, or does not want to be any more, it transforms fictional narration into 'a knowing exploration- by the

\footnotetext{
${ }^{37}$ Nathalie Grande, Le Roman au XVII siècle: L'exploration du genre (Rosny: Bréal, 2002).

${ }^{38}$ Sorel, La Bibliothèque françoise, p. 59 [197].

${ }^{39}$ See in the present volume Nicolas Correard's chapter, 'Criti-Comic Demonology: Picaresque Novels, Histoires Comiques, and the Supernatural'.
} 
characters and by the narrative - of a system of knowledge that both sustains and is sustained by the romance universe' ${ }^{40}$ Such self-consciousness does not so much modify romance's wonders as changes the reader's response to them.

Comments about changes of taste and passing fashions are indicative of patterns of production and consumption, and as such worth looking at closely. Studying the authorial and publishing mechanisms that partially govern reading modes may help us revisit a series of assumptions about early modern prose fiction. The renewal of the romance form in the $1650 \mathrm{~s}$, frequently noted by scholars, is one episode in the long-standing relationship between English and continental romance. According to Alice Eardley, ${ }^{41}$ such an episode is very much linked to the promotional activities of the Moseley family and their printing of French heroic romance in translation. There, theorizing on romance occurs through translation, not only of the romances themselves, but also of the elaborate critical material that accompanies them. In Scudéry's preface to Ibrahim, translated in 1653 alongside the romance itself, one finds a detailed prescription for a romance genre defined on the grounds of verisimilitude, against the marvellous associated with old chivalric romances. And Pierre-Daniel Huet's treatise on the origins of romance, quickly translated into English in 1672, demonstrates considerable continuity of interest in England in the theorizing of the French heroic romance. ${ }^{42}$ Still, prescriptive discourses, though influential, rarely render the richness and complexity of practical experimentations. Kirkman's quixotic translations of old romances give a startling

${ }^{40}$ See in the present volume Nandini Das's chapter, 'Romance and the Reinvention of Wonder in the Early Seventeenth Century'.

${ }^{41}$ See in the present volume Alice Eardley's chapter, 'Marketing Aspiration: Fact, Fiction, and the Publication of French Romance in Mid-Seventeenth-Century England'.

${ }^{42}$ Pierre-Daniel Huet, A Treatise of Romances and their Original (London: R. Battersby, for S. Heyrick, 1672). 
example of the 'simultaneously experimental and retrospective nature of fiction in the 1650s' - a decade described by Helen Moore as 'a significant and productive time of crossfertilization, self-differentiation, and theoretical articulation'. ${ }^{43}$ Similarly Guyda Armstrong demonstrates, in her chapter on the Italian novella collection, how another seemingly culturally 'obsolete genre' can be revivified through translation and domesticated to reflect the political affiliations of the producers, while adapting to wider literary trends in prose fictional production in English. ${ }^{44}$ Yet, cultural values shift over time, especially when caught in a volatile political climate. Both Guyda Armstrong and Brenda M. Hosington analyse English translations of Italian and French collections of short stories. While the 1620 publication of Boccaccio's Decameron offers a tamed, non-subversive elite courtly production in alignment with the cultural and moral norms of Jacobean Britain, Susan Du Verger's translations of Camus's collections of short stories, published in 1639, are to be understood in a Catholic and courtly context. By promoting 'histoires devotes' ('devout stories'), Du Verger explicitly offers an antidote to earlier and contemporary 'frivolous books' in the tradition of Boccaccio and Bandello, in order to foster 'an atmosphere of French-inspired courtly spirituality' ${ }^{45}$ Such a strategy stands in stark contrast with that of the Royal sympathizers who translated and published in 1652 the Choice Novels. A collection of (Catholic) erotic romances originating from the libertine Venetian Incogniti, the Choice

\footnotetext{
${ }^{43}$ See in the present volume Helen Moore's chapter, 'Admirable Inventions: Francis Kirkman and the Translation of Romance in the 1650s'.

${ }^{44}$ See in the present volume Guyda Armstrong's chapter, 'From Boccaccio to the Incogniti: The Cultural Politics of the Italian Tale in English Translation in the Seventeenth Century'.

${ }^{45}$ See in the present volume Brenda M. Hosington's chapter, 'Fact and Fiction in Susan Du Verger's Translations of Jean-Pierre Camus's Les Euenemens singuliers, Les Relations morales, and
} Diotrephe. Histoire Valentine'. 
Novels proposes 'a subversive cultural nostalgia as a strategy of creative resistance' that tells much about 'the cultural politics of transnational transfer in Commonwealth England'.

Collections of bibliographical references, and library and booksellers' catalogues offer a different standpoint from which to analyse dominant aesthetics and consumption patterns. These 'books about books' are not just catalogues of titles. They offer new ways to disseminate information about printed works. They foreground prevalent genres and dominant styles and, as such, are good indicators of the market trends of the time. They also offer to some degree a space for theorization. In other words, although we tend to emphasize their bibliographical contributions, their informative dimension should not overshadow their own potential impact on the field. To classify books is to reorder the social space which produces them; and such classifications may, in turn, influence readership(s). ${ }^{46}$ The Catalogue of The Most vendible Books in England was produced by Newcastle-upon-Tyne bookseller William London between 1657 and 1660. As one of the earliest attempts to list all English-language books, and prefaced by a substantial 'Introduction to the Use of Books', London's work is particularly valuable. Although there is no doubt about its financial incentive, London's catalogue is not just a selling guide. ${ }^{47}$ His catalogue is also issued to foster reading habits. It promoted learning among a wider public by facilitating access to authoritative books, at a time when the amount of printed production was perceived by

\footnotetext{
${ }^{46}$ I am very much indebted here to Michèle Rosellini who kindly sent me before publication her critical introduction to Charles Sorel, La Bibliothèque française (1667), edited by Filippo D’Angelo, Mathilde Bombart, Laurence Giavarini, Claudine Nédelec, Dinah Ribard, Michèle Rosellini, and Alain Viala (Paris: Honoré Champion, 2015).

${ }^{47}$ Margaret Schotte, “"Books for the Use of the Learned and Studious”: William London's Catalogue of Most Vendible Books', Book History 11 (2008): pp. 33-57 (pp. 38-9), doi:10.1353/bh.0.0009.
} 
booksellers and readers alike as overwhelming. ${ }^{48}$ Crucially, London chooses selection over exhaustiveness and promises 'that there is no choice Book omitted, but the best and most Books printed in England are here inserted' ${ }^{49}$ Compared to the bulk of the section devoted to 'Divinity Books', the one on fictional works may seem negligible, especially as London describes them as the 'least useful of any'. ${ }^{50}$ It is, however, noticeable that the romance titles 'seem to be exclusively domestic productions', and include among others Sydney's Arcadia, Barclay's Argenis, and the first part of Princess Cloria published in 1653 under the title Cloria and Narcissus. ${ }^{51}$ London clearly privileges material printed in England, and the importance of the vernacular sets his project in both a regional and a national framework. ${ }^{52}$ Yet it is worth noting that seventeenth-century prose fiction constituted itself through

${ }^{48}$ See Ann M. Blair, Too Much to Know: Managing Scholarly Information before the Modern Age (New Haven, CT: Yale University Press, 2010).

${ }^{49}$ Schotte, “"Books"”, p. 37; and William London, A Catalogue of The most vendible Books in England Orderly and Alphabetically Digested, Under the Heads of Divinity, History, Physick and Chyrurgery, Law, Arithmetick, Geometry, Astrology . ... with Hebrew, Greek and Latine for Schools and Scholars. The like Work never yet performed by any. Also, All sorts of Globes, Mapps of the World or in Parts .... All to be sold by the Author at his Shop in New-Castle (London: [s.n.], 1657).

${ }^{50}$ Schotte, “"Books”, p. 34; and London, A Catalogue of The most vendible Books in England, 'To the Most Candid and Ingenious Reader', sig. C2: 'For Romances, Playes and Poems, I do indeed take less paines to promote their study though I hinder not their sale; their names are not so wiredrawn as others are; They are least usefull of any.'

${ }^{51}$ Schotte, “"Books"', pp. 46-7. It also includes the Choice Novels, a collection of (Catholic) erotic novellas translated from the Italian language that is studied in the present volume by Guyda Armstrong.

${ }^{52}$ Schotte, “"Books”", p. 45. 
complex processes of delocalization and derivation across several vernacular languages. London's selection of French works in translation includes 'Artamnes, or grand Cirus', 'Cassandria' (both 1652 editions), 'Cleopatria', 'Clelia, by M. d. Scudery', and 'Illustrious Bassa'-all wares of the English publisher Humphrey Moseley. According to Alice Eardley, ${ }^{53}$ Moseley made a concerted effort in the 1650 s to foster and satisfy the demands of a large readership who wanted to read Scudéry and La Calprenède in English. The inclusion of these very romances in London's catalogue seemingly indicates that Moseley's effort was successful in bringing the new fashion north, and that London was able to capitalize on its commercial potential.

In his Bibliothèque françoise Sorel, too, chooses to select the books he thinks are worth reading. Where London provided very little information about his criteria, Sorel's position as a 'modern' situates his project in a broader cultural narrative. To those who would rather have their bookshelves full of classics, Sorel states that perfection can only be achieved if we include 'our French books' ${ }^{54}$ Even more than London, Sorel's tacit restriction to printed contemporary material opens up his selection to genres that the erudite elite would not normally consider worth reading. There is a clear emphasis on what was not yet called literature in the Bibliothèque françoise. ${ }^{55}$ Sorel pays close attention to new genres, mentions the latest literary modes promoted by French salon culture, and records social and cultural changes, such as the rising number of women authors choosing to write heroic romances. In other words, his Bibliothèque does not take an idealizing stance — what you should have on

\footnotetext{
${ }^{53}$ See Alice Eardley's chapter in the present volume.

${ }^{54}$ Sorel, La Bibliothèque françoise, 'Avant-Discours', p. 10 [2].

${ }^{55}$ As stated in the 'Avant-Discours', p. 11 [5], the selection includes books that may please everyone and anyone: the 'belles lettres' rather than the 'bonnes lettres'.
} 
your bookshelves — but a pragmatic one: what is sold and read. ${ }^{56}$ Sorel's selection reflects book-market production, thus giving valuable insight into the reading tastes of the public. The importance accorded to fashion is such that in one instance the book market is given precedence in determining the books authors should write:

Comme on aime aujourd'huy ces sortes de choses, \& que les Libraires ont veu que cela se vendoit bien, plusieurs ont fait de petits Recueils de leur part, sous le nom d'Euvres Galantes. ${ }^{57}$

('As we do love these sorts of things today, and booksellers have noticed that they sell well, a few authors have composed their own small collections, under the title of Euvres Galantes.') The precedence accorded to the vernacular in the sphere of knowledge is also understood in a national framework, as it appears in his epistle startlingly dedicated to France, rather than to the King. The rising importance of a French canon, however, is again to be situated in a transnational context. Sorel shows acute awareness of textual migrations through translations, imitations, and continuations. The Spanish started writing pastoral romances with some success, notes Sorel, but national pride dictated that French authors should imitate them, and Sorel sees Astrèe as a monument easily superseding the Spanish Diane de Monte-Major and the English Arcadie de la Contesse de Pembrok. ${ }^{58}$ Heliodorus's Aethiopica may be at the

\footnotetext{
${ }^{56}$ It is worth contrasting here La Bibliothèque françoise with Sorel's other book compendium: De la connaissance des bons livres ou Examen de plusieurs Auteurs [Paris: A. Pralard, 1671-3], edited by Hervé D. Béchade (Geneva: Slatkine Reprints, 1981).

${ }^{57}$ Sorel, La Bibliothèque françoise, p. 57 [190].

${ }^{58}$ Sorel, La Bibliothèque françoise, p. 54 [176]: ‘Mais nostre Nation n’est pas demeurée dans cette honte de ne pouvoir imiter les Estrangers: Ils ont mesme esté surpassez par l'Astrée de Messire Honoré d'Urfé'. Both texts quoted in translation: La Diane de Monte-Major stands for Los Siete
} 
origin of the heroic romance, but it has been naturalized through translation, thus meeting the fate of the Spanish Amadis, which became 'a French then a European property, endlessly continued in serial fashion by subsequent translators and authors' ${ }^{59}$ If success in the book market sanctions national pride as well as international superiority in Sorel's Bibliothèque françoise ${ }^{60}$ Warren Boutcher demonstrates that authors such as Cervantes hold more critical views about the debased translations and continuations produced by transnational commercial networks linking printers and booksellers across Europe. ${ }^{61}$ Both points of view have their importance, and indeed should be considered as mirroring each other. If Sorel's national pride falls into a more conventional narrative, where forms and genres keep to the translatio studii representational model, Cervantes's focus on poor copies and falsified originals, once contrasted with the historical realities of the transmission of his own work, present a more complex model. While the 'Hispano-French translatio of Cervantes's name and works' involved high-prestige translations by translators of status, other commercial bagatelles analysed by Boutcher simultaneously circulated in all sorts of forms and languages. Episodes creatively appropriated, mock-chivalric 'cartels', and staged entertainments incorporating

libros de la Diana de Jorge de Montemayor and L'Arcadie de la Comtesse de Pembrok for Philip Sidney's The Countess of Pembroke's Arcadia.

${ }^{59}$ See in the present volume Warren Boutcher's chapter, 'Transnational Cervantes: Text, Performance, and Transmission in the World of Don Quixote'; and Andrew Pettegree, 'Translation and the Migration of Texts', in Borders and Travellers in Early Modern Europe, edited by Thomas Betteridge (Aldershot: Ashgate, 2007), pp. 113-25. On the translation of Amadís from French into English, see Helen Moore's chapter in this volume.

${ }^{60}$ Sorel, La Bibliothèque françoise, p. 55 [183]; p. 58 [193]: 'Je nomme des Livres qui sont Espagnols d'origine, mais qui ayant esté faits François par la Traduction, peuvent tenir leur rang en ce lieu.'

${ }^{61}$ See Warren Boutcher's chapter in this volume. 
Quixotic 'new things' unsettle, most effectively, generic genealogies by producing a multipolar constellation of textual productions whose derivativeness would have been unmistakable by contemporaries.

Don Quixote is all the more famous for being a transnational success staging a fictional reader whose taste was behind the time. As much as seventeenth-century prose fiction built itself up as a genre, by rejecting the 'old' romance and its chivalric ethos, Cervantes's hidalgo de la Mancha made it impossible for readers across Europe to enjoy these old books in the same careless way ever again. Popular prose fiction in early modern Europe often had a transnational readership, and scholars usually note the correlations among old-fashioned romance, popular readership, and cheap, badly printed books such as those of the French Bibliothèque bleue. ${ }^{62}$ Yet the success of the popular press across Europe should not lead us to draw too stark a distinction between divergent reading publics belonging to different social groups with distinct tastes. Although in the long run there is 'an increasing divergence between the material published in the Bibliothèque bleue and that read by the cultural elite', ${ }^{63}$ new books were not necessarily the preserve of a cultural elite, no more in fact than old chivalric romances were unanimously disdained for being associated with the poorly

\footnotetext{
${ }^{62}$ See Henri-Jean Martin, Livre, pouvoirs et société à Paris au XVII siècle, 1598-1701, preface by Roger Chartier, 3rd edn. (Geneva: Droz, 1999); Lise Andries, La Bibliothèque bleue au dixhuitième siècle: une tradition éditoriale (Oxford: Voltaire Foundation, 1989); Victor Edward Neuburg, Popular Literature: A History and Guide from the Beginning of Printing to the Year of 1897 (London: Woburn Press, 1977); Peter Burke, Popular Culture in Early Modern Europe (London: Temple Smith, 1978); Margaret Spufford, Small Books and Pleasant Histories: Popular Fiction and its Readership in Seventeenth-Century England (London: Methuen, 1981).

${ }^{63}$ Lise Andries, 'Was the Novel a Popular Genre in Early Modern France?', in Remapping the Rise of the European Novel, pp. 249-60 (p. 254).
} 
educated. After all, Don Quixote, though mad, was of noble descent, and so was the penniless Francion who admits having devoured old chivalric romances when attending college. ${ }^{64}$ If fictional characters loved reading romances, we also find testimonies of readers belonging to the cultural elite acknowledging (sometimes guiltily) their lasting love for books fallen into disrepute. In other words, one has to assess actual consumption patterns against printers' and booksellers' marketing strategies of high- or low-quality printed material. The bookseller and author Francis Kirkman may exemplify admirably an unabashed love for chivalric romance; his non-elite translations analysed by Helen Moore 'exemplify the transitional character of the 1650s and the accommodations its readers and writers made in assimilating their "old" tastes with the "new" direction of fiction'. ${ }^{65}$ Similarly central to Alice Eardley's chapter is the distinction between the 'appearance of high cultural value' attributed to French heroic romances and their actual readership of middle-class readers on both sides of the Channel. In France, the old romance was criticized for its language, stock characters, and stereotyped plot lines as well as its outrageous use of magic. ${ }^{66}$ If few people liked them, says Sorel, ${ }^{67}$ that did not prevent them being read and appraised, even by those who promoted the very poetics that excluded their wonders from the literary scene. Jean Chapelain, who championed the use of

\footnotetext{
${ }^{64}$ Charles Sorel, Histoire comique de Francion. Édition de 1633, edited by Fausta Garavini (Paris: Gallimard, collection Folio Classique, 1996), pp. 175, 187.

${ }^{65}$ See Helen Moore's chapter in the present volume, and Turner, "Romance” and the Novel', p. 66.

${ }^{66}$ Esmein, ed., Poétiques du roman, pp. 30-2.

${ }^{67}$ Sorel, La Bibliothèque françoise, p. 53 [175]: 'Peu de Gens les ayment aujourd'huy, ou s'ils les veulent voir quelquefois, ils s'arrestent à ceux qui leur peuvent tomber sous leurs mains. L'ancienneté de leur langage déplaist à ceux qui ne veulent que des choses à la mode.'
} 
verisimilitude, also wrote a eulogy of the old chivalric romances. ${ }^{68}$ Caught by Ménage and Sarasin with a Lancelot open on his desk, Chapelain launches himself into a defence of those old books, on the grounds that they teach us something valuable about our past, whether in terms of history of the vernacular or about mores, values, and customs. Such promotion of an antiquarian reading may seem paradoxical at first, and a means to excuse a taste for wonder which survived the new fictional regime. Yet Chapelain did not read Lancelot with the quixotic absorption Cervantes suggested, no more, in fact, than earlier readers did. One could even argue, with Nandini Das, that Don Quixote himself had a far more ambiguous attitude towards wonder than his hacking of the pasteboard puppets might suggest. ${ }^{69}$ The selfconscious consumption of wonders, as promoted by the Don, acts here as a reminder that different levels of reading may coexist, or that embedded reading pacts can be challenged, transformed, and parodied. How prose fiction was read is as important to determine as what was read in the first place.

The reader's expectations are central to seventeenth-century poetics, and become even more so when considered across generic, linguistic, and geo-political boundaries. The closing decades of the seventeenth century saw the publication of a series of innovative prose narratives which explored differently the relationship between history and fiction- to such an extent that Pierre Bayle saw this habit of mixing fictional narratives with historical facts as

${ }^{68}$ See Jean Chapelain's letter to Antoine Godeau, dated 29 November 1630: Lettre sur la règle des vingt-quatre heures [Ms BNF, fonds français, 12847]; and 'De la lecture des vieux romans', in Opuscules critiques, edited by Alfred C. Hunter (Paris: Droz, 1936), pp. 205-41.

${ }^{69}$ See in the present volume Nandini Das's chapter; and Miguel de Cervantes Saavedra, The Second Part of the History of the Valorous and Witty Knight-errant, Don Quixote of the Mançha, trans. Thomas Shelton (London: Printed [by Eliot's Court Press] for Edward Blount, 1620): pp. 173-4. 
detrimental to historical truth as a whole. ${ }^{70}$ This renewal of the novelistic form is frequently noted by scholars, yet Bayle should not have worried too much. Fiction does not rule out facts, nor does it simply align with history, even if it pretends to be as good as true. In a genre building its prestige on the recourse to history, ${ }^{71}$ generic negotiations are to be expected, and will quite often comply with the dominant narrative of an evolutionary move towards higher standards of verisimilitude. Such a narrative, however, often fails to represent the particularities of the texts' generic negotiations. Argenis offers 'a Fable like a Historie' full of 'strange events' and 'inventions', thus taking liberties with 'the truth of a History'. ${ }^{72}$ Princess Cloria is a powerful political fantasy whose textual ambiguities cannot be reduced in the act

${ }^{70}$ Pierre Bayle, Dictionnaire historique et critique [5th edn., 1740] (Geneva: Slatkine Reprints, 1995): article 'Nidhard', Remarque C: 'C'est un inconvénient qui s'augmente tous les jours par la liberté qu'on prend de publier les Amours secrettes, l'Histoire secrette, \&c, de tels \& de tels Seigneurs, fameux dans l'Histoire. Les Libraires \& les Auteurs font tout ce qu'ils peuvent, pour faire accroire que ces Histoires secrettes ont été puisées dans des Manuscrits anecdotes: ils savent bien que les Intrigues d'amour, \& telles autres Avantures plaisent davantage quand on croit qu'elles sont réelles, que quand on se persuade que ce ne sont que des inventions. De là vient que l'on s'éloigne autant que l'on peut de l'air romanesque dans les nouveaux Romans; mais par là on répand mille ténébres sur l'Histoire véritable, \& je croi qu'enfin on contraindra les Puissances à donner ordre que ces nouveaux Romanistes ayent à opter; qu'ils fassent, ou des Histoires toutes pures, ou des Romans tout purs; ou qu'au moins ils se servent de crochets pour séparer l'une de l'autre, la vérité \& la fausseté.'

${ }^{71}$ See Esmein, ed., Poétiques du roman, p. 35; Delphine Denis, 'Le Roman, genre polygraphique?', Littératures classiques 49 (2003) ('De la polygraphie au XVII' siècle', edited by Patrick Dandrey and Delphine Denis): pp. 339-66.

${ }^{72}$ As stated by Nicopompus (who represents the author, Barclay), pp. 131-2, quoted by Alex Davis, from the 1628 translation by Robert Le Grys. 
of deciphering, even if the use of keys encodes a reading practice compounded by readers' eagerness for political gossip. ${ }^{73}$ Camille Esmein-Sarrazin's analysis of Lafayette's uses of historical material in the crafting of her novels and memoirs, likewise, suggests a creative continuum from history to fiction that 'does not permit a rigorous isolation of the different types of writing' ${ }^{74}$ Indeed a rigorous isolation would not render the generic ambiguity of history, whose practice vacillates from erudite report to a detailed narration that, 'because of its popularizing aims and its literary form, could be termed novelistic' ${ }^{75}$ It is history understood as the creation of a narrative that influenced seventeenth-century prose fiction. Lafayette uses precise and well-founded historical information to give her fictional narratives an aura of truth. Historical plausibility may sometimes yield to moral truth; but then the historian was often viewed as a moralist. While in texts such as Lafayette's, 'fiction supplements history and fills in the gap', Thibaut Maus de Rolley's chapter explores other avenues by concentrating on how a (French) legal document pertaining to a legal case - the condemnation of the priest Gaufridy — was translated into English and fashioned as a literary

${ }^{73}$ The Princess Cloria, 'Preface', in Salzman, ed., An Anthology, p. 214.

${ }^{74}$ See in the present volume Camille Esmein-Sarrazin's chapter, 'Fact and Fiction in the Works of Madame de Lafayette: A Poetics of Secrets and Gossip'.

${ }^{75}$ See in the present volume C. Esmein-Sarrazin's chapter; and Steve Uomini, Cultures historiques dans la France du XVII siècle (Paris: L'Harmattan, 1998). On the debate in seventeenth-century French dramatic theory on the 'vrai' vs. 'vraisemblable', and the Aristotelian distinction between the role of particulars and of universals in narrative, see Bérenger Boulay, 'Histoire et narrativité, autour des chapitres 9 et 23 de la Poétique d'Aristote', Lalies 26 (Paris: Éditions Rue d’Ulm/Presses de l'École Normale Supérieure, 2006), pp. 171-87, also available online as part of the Atelier series of Fabula, <http://www.fabula.org/ressources-atelier.php>. I am grateful to Neil Kenny for pointing out this reference to me. 
account. ${ }^{76}$ The resulting text is close to the genre of criminal biography, such as the Faust story, while borrowing its rhetoric from Elizabethan news pamphlets. Yet, argues Maus de Rolley, 'the rewriting is not so much a betrayal of the archive [as] an exercise in interpretation thereof', thus emphasizing the hybrid nature of a text caught between legal fact and fictional invention successfully relocated from France to England. Such an example is an invitation to reconsider the symbolic capital of what has sometimes been described as an 'undifferentiated matrix' of news reports and fictional narratives. ${ }^{77}$

Prose fiction defined itself very much by contrast with, and by reference to other genres with a more established theoretical tradition. ${ }^{78}$ If history proved particularly influential in the shaping of new forms, the relationship between prose fiction and theatre was, likewise, one of mutual influence. ${ }^{79}$ Important debates were conducted among writers and theoreticians, both within national cultures and across them - the cross-Channel exchange proving particularly rich and active. At the core of such questioning, that engaged with a range of aesthetical and moral issues, were the ways in which stage and page induced the reader's intellectual and

${ }^{76}$ See in the present volume Thibaut Maus de Rolley's chapter, 'The English Afterlife of a French Magician: The Life and Death of Lewis Gaufredy (1612)'.

${ }^{77}$ Davis, Factual Fictions, p. 67. See McKeon, 'Review: The Origins of the English Novel'; Paige, Before Fiction, pp. 20-1.

${ }^{78}$ It is worth remembering that prose fiction had escaped theoretical prescription more than genres such as drama or epic - except to the extent that it was conflated with the latter-because it had not been discussed by Aristotle.

${ }^{79}$ It is not our goal here to revisit the importance of early modern connections between stage and page: they have received ample attention in recent scholarship. We are more interested here in the way in which this interplay illuminates the reader's response: how prose fiction was read at the time, or rather, how it was assumed it would be read by authors and critics alike. 
emotional engagement. There was indeed much debate about their content, their dubious role in teaching how to eschew vice and emulate virtue, or the way the transmission of learning (whether moral or of a more varied kind) was integrated in the making of fiction. The old motto placere, docere, movere ('to please, to teach, to move') cropped up here and there in the texts and their paratexts as a means of waiving objections. And the devout reaction in France against the danger of the stage ${ }^{80}$ reflects to some extent the concerns expressed earlier in the century by Camus (among others) about the libertine fantasies of short stories and their ability to stimulate the reader's passions. Others, like Bernard Lamy, ${ }^{81}$ analysed human craving for emotional stimulation, while pointing to the narcissistic dimension of fictional identification. Such a shift in focus from generic uncertainties to the reader's response is explored by Ros Ballaster's chapter on the transmission of French short prose fictions to the English stage: 'how [do] audiences come to perceive the fictions they consume as "bringing forth alive" the conceptions of their minds" ${ }^{82}$ The distinction drawn here between what is 'true' and what is 'alive' displaces the fact and fiction dilemma most suggestively: fiction, it seems, differentiates itself by the affective response it elicits from its reader. The ways in which the restored stage responded to the imported fictional plots and practices of narration demonstrate both its openness to literary experiments and the difficulty the stage had to bring

\footnotetext{
${ }^{80}$ Laurent Thirouin, L'Aveuglement salutaire. Le réquisitoire contre le théâtre dans la France classique (Paris: Honoré Champion, 1997), pp. 20, 40-5.

${ }^{81}$ Bernard Lamy, Nouvelles Reflexions sur l'Art Poëtique. Dans lesquelles en expliquant quelles sont les causes du plaisir que donne la Poësie, \& quels sont les fondemens de toutes les Regles de cet Art, on fait connoître en même têms le danger qu'il y a dans la lecture des Poëtes (Paris: A. Pralard, 1678; Geneva: Slatkine Reprints, 1973).

${ }^{82}$ See in the present volume Ros Ballaster's chapter, “"Bring(ing) Forth Alive the Conceptions of the Brain": The Transmission of French to English Fiction between Stage and Page'.
} 
forth alive the new narrative standards, as it 'often departed into the grotesque and the performative'. When fiction produces its own literary alternatives and performances, the resulting forms may prove startling even to their targeted audiences. Lee's widely unfaithful adaptation of La Princesse de Clèves purposefully thwarted 'the imaginative expectations of an audience attracted to the play by the familiar title'.

Seventeenth-century prose fiction is a story of literary transmission and cultural exchange through complex processes of delocalization, translation, and derivation across national, linguistic, and generic boundaries. It is a story of books written, published, sold, translated, imitated, parodied, plagiarized; of motifs and tropes creatively appropriated and transformed. It is also a story of readers in a period that saw prose reading as an ever-growing protean concern, engaging with a range of different issues, whether moral, aesthetic, or more commercial. Above all, it is a story that unsettles, most effectively, generic genealogies by producing such diverse patterns of textual productions and consumptions. The selection of case studies presented here captures some of the richness of seventeenth-century crosscultural experiment(s). ${ }^{83}$

\footnotetext{
${ }^{83}$ My warmest thanks to Nandini Das, Mairéad Hanrahan, Neil Kenny, Andrew Leak, and Caroline Warman for their comments on previous versions of this introductory chapter.
} 


\section{Abstract}

Innovation in prose fiction took Europe by storm during the seventeenth century, and no single umbrella term can capture the astonishing variety of fictional experiments witnessed at the time. This is a story of literary transmission and cultural exchange through complex processes of delocalization, translation, and derivation across national, linguistic, and generic boundaries; a story of books written, published, sold, translated, imitated, parodied, plagiarized; and a story of readers in a period that saw prose reading as an ever-growing protean concern, engaging with a range of different issues, whether moral, aesthetic, or more commercial. 'Seventeenth-Century Fiction in the Making', observant that fiction in this period was not restricted to literary texts or even 'coterminous with literature', and of the interchange between classical and vernacular languages, popular and elite cultures, stage and page, provides an enhanced understanding of the diversity of the reception and perception of prose fiction at the time. It aims to unsettle generic genealogies by giving a sense of the variety of old and new forms that readers craved, and that could not be subsumed within a limited definition of the novel.

Keywords

book market, fiction, innovation, novel, prose, reception, romance, translation, vernacular 